\title{
Key people involved in the history of the ILL
}

This list is incomplete (additional names have been added in this revision of Jacrot's book); it is not possible to mention all those who have contributed to this story. For scientists and engineers of the ILL the nationality is not specified.

[2018 addition: It is only right to mention at this point the engineers and physicists who designed the reactor and its experimental environment. This list is taken from the "Bulletin d'Informations Scientifiques et Techniques" of the CEA: BIST 165 (1971) and BIST 166 (1972). https://wwwarchive.ill.fr/about/what-is-the-ill/history/ ill-founding-papers/]

J. CHATOUX, "Description of the reactor and main options."

L. BREGEON, F. LAFAURIE and J.P. SCHWARTZ, "Neutron and thermal aspects. The fuel element."

D. COLZY, G. DUPUY and J.P. MARTIN, “The nuclear system of the high flux reactor."

M. CHAZALON and Y. LECUYER, "The cooling circuits and detritiation."

G. LHOR, "The fuel handling."

M. DEBRU, "The control and command system."

R. LEVET, "Civil engineering works and containment of the reactor building."

J. BUREAU DU COLOMBIER and H. REUTLER, "Safety aspects of the reactor."

P. AGERON, "Experimental possibilities."

P. AGERON, J.M. ASTRUC, H. GEIPEL and J. VERDIER, "The cold neutron source of the high flux reactor."

G. BOHME, W. DREXEL and F. WUNDERLICH, "The hot source of the high flux reactor."

J.C. FAUDOU, "In-pile systems for nuclear physics."

P. AGERON and P.A. BLUM, "The neutron beam tubes."

G. GOBERT, "The solid state physics spectrometers." 


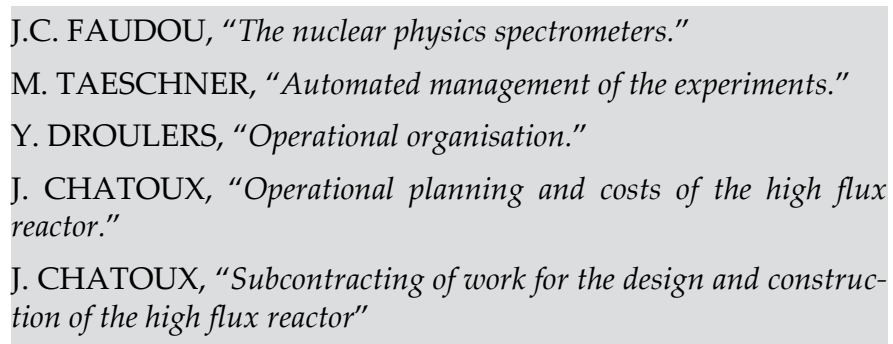

ABELE Hartmut: Physikalisches Institut, University of Heidelberg

ABRAGAM Anatole: French physicist, Director of Physics at the CEA (1965-1970) and professor at the Collège de France.

ALLEN Geoffrey: English chemical-physicist, professor at the University of Manchester (1965-1975), chairman of SRC in 1977

AGERON Paul (1931-1998): engineer and physicist who built the cold source and neutron guides

ALDEBERT Pierre: Thesis student from the French solar furnace at Montlouis

ARMBRUSTER Peter: nuclear physicist. Deputy Director (1989-1992)

ARNDT Ulrich (1924-2006): crystallographer of biological molecules, coming from Max Perutz's group, ILL: 1972-1973

ASTRUC Jean-Marie: reactor engineer

AVERBUCH Pierre: physicist university of Grenoble

AXMANN Anton: engineer and physicist responsible for electronics

BACON George: English physicist who has written much on neutrons

BALLIGAND Pierre (1917-1987): deputy director of the CENG

BAUER Ekkehardt: third head of reactor service (1989-2003), he was the ILL responsible for the reactor reconstruction

BECKURTS Heinz (1930-1986): physicist Karlsruhe, co-author of the reactor project with Robert Dautray, was murdered by the Red Army faction

BERTAUT Felix (1913-2003): head of crystallography at the CENG and CNRS in Grenoble

BLACKETT Patrick: English physicist, Nobel Prize 1948

BLOW David (1931-2004): English protein crystallographer, one time student of Max Perutz; Cambridge then London 
BOTHE Walter: German physicist, Nobel prize 1954

BREGEON Louis: project engineer group, in charge of reactor physics

BRENIG Wilhelm: Max Planck Institute for Solid State Research in Stuttgart, from 1970 to 1978

BROCHIER Dominique: engineer, cryogenics

BROCKHOUSE Bertram (1918-2003): canadian physicist Nobel prize in 1994 for his pioneering work on triple-axis spectrometers BROWN Jane: physicist crystallographer

BRÜGELMANN Silvia: Maier-Leibnitz's secretary

BURLET Paul: crystallographer of CENG

CHARVOLIN Jean: physicist deputy director and then director (1989-1994) during the reconstruction of the reactor

CHATOUX Jean: head of reactor project

CHIEUX Pierre: physicist

CURRAT Roland: physicist

CREYSSEL Pierre: executive director of the CNRS

CRIBIER Daniel: physicist at Saclay, director of the Léon Brillouin institute

CURIEN Hubert (1924-2005): director of the CNRS department of physics, then director CNRS

DAINTON Frederick: English chemist, chair of the University Grants Committee (UK)

DAUTRAY Robert: author of the reactor project, then he had very great responsibilities in the CEA of which he became high commissioner

DIANOUX José: physical chemist

DORNER Bruno: physicist ILL, specialist 3-axis spectrometers

DOUCHIN François: engineer, one of the founders of the trade union SA-ILL

DREYFUS Bernard (1928-2005): physicist, deputy Director (1973-1976)

DREXEL Winfried: physicist

DROULERS Yves: first head of reactor service

EGELSTAFF Peter: Harwell physicist, pioneer of inelastic scattering and cold sources, worked in Canada at the University of Guelph for over 20 years

von EGIDY Till: nuclear physicist

EISERMANN Werner: deputy head of the reactor project 
EMBLING John Francis (Jack): Deputy Under-Secretary, Department of Education and Science; Council for Scientific Policy from SRC

FAUDOU Jean-Claude: engineer, head of the DPT (Départment Projets et Techniques)

FEILDEN Geoffrey Bertram Robert (Bob): English engineer, Deputy Director General, British Standards Institution; Council for Scientific Policy from SRC

FENDER Brian: chemist, deputy director, then director (1980-85)

FIEBIGER Nikolaus: German physicist, professor in Frankfurt/ Main (1963)

FILHOL Alain: crystallographer, thesis student, then physicist

FLEISCHMANN Rudolf: German physicist, teaching assistant to Walter Bothe

FLOWERS Brian: head of the Science Research Council (SRC)

FRANZETTI Franco: second head of the reactor service

FREUND Andreas: physicist, head of the Monochomator group

FRIEDEL Jacques: physicist Orsay

FULDER Peter: theoretician, head of Munich group GARIOD Roger: engineer CENG

de GENNES Pierre Gilles: theoretician Saclay, then Collège de France, Nobel Prize (1991)

GENTNER Wolfgang: German nuclear physicist

GHOSH Ronen (Ron): physical chemist

GOBERT Guy: mechanical engineer

GÖPPERT-MAYER Maria: German-born American theoretical physicist, and Nobel prize in Physics in 1963

GREIFELD Rudolf: German member of the ILL steering committee, sacked in 1976

GUINIER André (1911-2000): physicist Orsay

HALDANE Duncan: post-doctoral researcher in the ILL's Theory group from 1977 to 1981; winner of the Nobel Prize in Physics in 2016

HASENCLEVER Wolfgang: first chief administrative officer

HAUSSER Karl Wilhelm: first director of the physics department of the Kaiser Wilhelm Institute for Medical Research (Max-Planck-Institute).

HEIDEMANN Anton: physicist, student of Maier-Leibnitz HEWAT Alan: physicist crystallographer from Harwell HIGGINS Julia: physical chemist, elected Fellow of the Royal Society (FRS) in 1995 
HOROWITZ Jules: (1921-1995) see section 2.1

IBEL Konrad: physicist

IPOUSTEGUY Jean Robert: French sculptor and painter (1920-2006)

JACQUEMAIN Michel: head of technical services

JACQUINOT Pierre: Professor in spectroscopy and DirectorGeneral of the CNRS (1962-1969)

JOLLIFFE Christopher: Science Division, SRC; led the first negotiations for the SRC

JUST Wilhelm: Austrian physicist; abandoned physics in 1989 to become a psychoanalyst

KENDREW John (1917-1997): physicist, protein crystallography, Nobel Prize 1962

KLAR Bertram: physicist

KLEY Walter: physicist Euratom (Ispra)

KOUTS Herbert: head of the Brookhaven reactor project

KOWARSKI Lew (1907-1979): physicist of Russian origin in Joliot's team, he was a pioneer of reactor physics, he directed the construction of the first reactor of the CEA, then left for CERN

LACAZE Albert: physicist engineer in cryogenics at the university of Grenoble

LAJZEROVITZ Janine: professor at the University of Grenoble, crystallographer

LEHMANN Mogens (Mons): physicist

\section{LE SOURNE Mathurin: computer engineer}

LOMER Mick: Atomic Energy Authority (AEA); member of the SRC-AEA Joint Research Programme; first British deputy director from 1973 to 1974.

LOOSCH Reinhart: German, Under-Secretary of the Federal Ministery for Education and Science, ILL Steering Committee in 1971

LOTH Wilhelm: German visual artist (1920 - 1993)

LOWDE Ray: physicist Harwell

MAIER Bernd: physicist, first scientific secretary

MAIER-LEIBNITZ Heinz (1911-2000): see section 2.2

MAMPE Walter: nuclear physicist

MARTIN Jean-Paul: project engineering group, delegated construction supervisor (1968-1971), reactor vessel replacement supervisor (1991-1994)

MATHO Konrad: theoretical physicist

MASON Saxon (Sax): physicist 
MERRISON Alexander Walter (Alec): British physicist born in 1924. Vice-chancellor of University of Bristal; Council for Scientific Policy from SRC

MEZEI Ferenc: physicist inventor of the neutron spin echo-technique and supermirroirs

MITCHELL William (1925-2002 ): responsible in the UK committee for the use of neutron beams (NBRC)

MOLL Eberhard: nuclear physicist, one of the founders of the trade union SA-ILL

MÖSSBAUER Rudolf (1929-2011): second director, Nobel Prize in physics 1961

MOUSSA André: Grenoble nuclear physicist

NEEL Louis (1904-2000): see section 2.3

NEWPORT Ron: responsible for SERC

NIEFNECKER Hervé: nuclear physicist CENG

NOZIERES Philippe: theoretical physicist, member of the Academy of Sciences

PALEWSKI Gaston: French politician, President of the Constitutional Council of France from 1965 to 1974

PERRIN Francis: High Commissioner CEA from 1951 to 1970

PEYREFITTE Alain: French Deputy Minister for Scientific Research and Atomic and Space Matters

PLATTENTEICH Adalbert: Head of Administration from 01/11/73 to $31 / 12 / 77$

PRETSCH Joachim (1909-1970): head of the German division of nuclear research

SCHELLING Erich: German architect in Karlsruhe who supervised the development of Karlsruhe's nuclear research centre

SCHLEMMER Oskar: German artist (painting, sculpture, theater) from the Bauhaus (1888-1943)

SCHNEIDER Jochen: physicist

SJÖLANDER Alf: Swedish physicist from Chalmers

STEINER Michael: German physicist from Tübingen University STOLTENBERG Gerhard: German Minister for Scientific Research

RAIEVSKY Victor: physicist, proponent of the Euratom pulsed reactor

RENOUPREZ Albert-Jean: French physicist from CNRS, specialist of catalysis

REUTLER Herbert: engineer project group responsible for safety issues

ROTH Michel: physicist 
SCHERM Reinhard: physicist early ILL, became director 20 years later

SCHOENBORN Benno: protein crystallographer, pioneer at Brookhaven in the use of neutron crystallography for proteins

SCH ḦRPF Otto: physicist

SCHWEIZER Jacques: physicist very active in the development of crystallography at CENG

SHULL Clifford (Cliff): pioneer in crystallography with neutrons, Nobel Prize in physics 1994

SIRET Yvon: responsible for computing

SPRINGER Tasso: physicist deputy director (1977-1980) and director (1980-1982)

STIRLING William (Bill): ILL physicist (1973-1987), became director general of the ESRF in 2001, then ILL director (2014-2016)

STUHRMANN Heinrich: physicist developed neutron applications in biology

TASSET Francis: physicist. With BROWN Jane and FORSYTH Bruce, he invented CRYOPAD, a technique allowing the spherical polarisation analysis of neutrons.

TAESCHNER Michael: computer engineer

THOMAS Michel: physicist

TIPPE Armin: German physicist from the Max-Planck Institute

TOCHETTI Defendente: physicist

VAN VLECK John: American physicist and mathematician (1899-1980), Nobel Prize in Physics in 1977

VALENTINE Jim: Neutron Beam Research Committee from SRC. VILLAIN Jacques: theoretical physicist

VETTIER Christian: thesis student, physicist, became deputy director 1999

VOLINO Ferdinand: physicist from CEA-CENG

WADE B. (Mrs.): Reactor Division of the AERE; Neutron Beam Research Committee from SRC

WEIL Louis (1914-1968): professor at the university of Grenoble, director of research low temperature laboratory (CRTBT) Grenoble

WHITE John: physical chemist Australian deputy director (1975-1977) and director (1977-1980)

WOOD W. (Mr.): Reactor Division of the AERE; Neutron Beam Research Committee from SRC

ZACCAI Giuseppe (Jo): physicist, later biologist 
